\title{
AN OVERVIEW OF THE DEVELOPMENTS OF HALAL CERTIFICATION LAWS IN MALAYSIA, SINGAPORE, BRUNEI AND INDONESIA
}

\author{
Rokshana Shirin Asa ${ }^{1}$
}

\begin{abstract}
Halal is not solely a religious issue; it has reached the domain of halal trade and become a global halal trademark for quality affirmation. Today, halal has become a noteworthy issue in trading and trade related matters. Many countries consider halal as a new trademark for marketing. Halal labeling serves as a medium for strengthening the belief of Muslim consumers. It is a symbol of guaranteeing the purity of manufacturing the products. This promising large halal market has created an intensified attention around the world. Muslim and non-Muslim countries are developing their own halal matters, halal certification process, laws and regulations in order to compete for the global halal market. Countries with minority Muslim populations such as Singapore, the U.S.A, Canada, Japan, Australia, New Zealand and South Africa have become important providers to the world's halal trade. For that reason, this article discusses the international initiatives taken by some Muslim and non-Muslim countries like Malaysia, Singapore, Brunei and Indonesia for the development of halal certification vis-a-vis their legal systems.
\end{abstract}

Assistant Professor, Department of Social Science, BGMEA University of Fashion \& Technology, Nishatnagor, Turag, Dhaka 1230, Bangladesh, rokshanashirin@, buft.edu.bd 
Hence, the purpose of this discussion is to propose for better ways of implementing the Malaysian halal certification laws.

Keywords: halal, Halal Certification Laws, implementation, Global Halal Market, halal logo

\section{INTRODUCTION}

Halal products and services such as food, confectioneries, food ingredients, consumer goods, logistics, cosmetics and pharmaceuticals have drawn a lot of attention of the local and international community, especially in Muslim countries. Today, halal has become a noteworthy issue in trading and trade related matters. Many countries consider halal as a new trademark for marketing. Halal labeling serves as a medium for strengthening the belief of Muslim consumers. ${ }^{2}$ It is a symbol of guaranteeing the purity of manufacturing the products. ${ }^{3}$ This promising large halal market has created an intensified attention around the world. ${ }^{4}$ In the past, Muslim states internally substantiate their maximum demands of food or had them imported from other Muslim countries. However, Muslim consumers are rapidly increasing and that has overtaken the available food supply. Apparently, the supplies of halal products are quite inadequate; therefore, to achieve the demand of consumers, some Muslim states have to import halal food from other developed countries or non-Muslim states. ${ }^{5}$ These provide reasons for states to develop their own halal regulation for the expansion of their export and import of halal products.

The expression 'halal' is not solely a religious issue; it has reached the domain of halal trade and become a global halal trademark for quality affirmation. Muslim and non-Muslim countries are developing their own halal matters, halal certification process, laws and regulations in order to compete

2 Mohamed, Z., Shamsudin, M. N., \& Rezai, G., 'The Effect of Possessing Information About Halal Logo on Consumer Confidence in Malaysia,' Journal of International Food \& Agribusiness Marketing, vol. 25 (2013): 73-86, sup1.

3 Said, M. M., \& Elangkovan, K., 'Halal Label and the Ethics of Business: An Analytical View from Producers,' Australian Journal of Basic and Applied Science, vol. 7, no. 6 (2013): 613-621.

4 Soesilowati, E. S., 'Business Opportunities for Halal Products in the Global Market: Muslim Consumer Behaviour and Halal Food Consumption,' Journal of Indonesian Social Sciences and Humanities, vol. 3 (2011): 151-160.

5 Marzuki, S. Z. S., Hall, C. M., \& Ballantine, P. W., 'Measurement of Restaurant Manager Expectations Toward Halal Certification Using Factor and Cluster Analysis,' Procedia-Social and Behavioral Sciences, vol. 121 (2014): 291-303. 
for the global halal market. Globally, there are about 122 halal certification bodies around the world that are involved in halal certification ${ }^{6}$ out of which a total of 42 bodies recognized by JAKIM, ${ }^{7}$ and 44 are recognised by Lembaga Pengkajian Pangan, Obat-Obatan dan Kosmetika-Majelis Ulama Indonesia (hereafter termed as LPPOM-MUI) ${ }^{8}$ (List of Halal Certification Bodies, 2019).

Halal today is not merely a spiritual expression of what is permissible or not; nevertheless, it is unification between the Muslim world and the recent growing global market of production, trade and consumption. ${ }^{9}$ Countries with minority Muslim populations such as Singapore, the U.S.A, Canada, Japan, Australia, New Zealand and South Africa have become important providers to the world's halal trade. ${ }^{10}$ For that reason, this article discusses the International initiatives taken by some Muslim and non-Muslim countries for the development of halal certification vis-a-vis their legal systems. Most of the world's countries have their own halal regulations to ensure that the food supplied to Muslim consumers is certified halal according to Shariah. Muslim countries are relying on halal certifications set by the recognized trustworthy certifying bodies that are already in place.

The halal certificate acts as a marketing tool to the halal food market. For considering this mandates only four ASEAN nations such as Malaysia, Singapore, Indonesia and Brunei has adopted halal certificate related legislations more or less. Hence, this article is to confine within these four ASEAN countries. It is one of the pivotal limitations of this article. In addition Malaysia intends to succeed in different advancement in decentralizing halal standards by creating an imperative outline in ASEAN countries, stated by the Malaysian International Trade and Industry Minister, Mustapa Mohamed. He

6 Evangelia Komitopoulou, 'The Growth of the Halal Market and the Role of Halal Certification,' http://www.sgs.com/en/news/2014/10/the-growth-of-the-halalmarket-and-the-role-of-halal-certification, accessed on 21 December 2018.

7 Management Division, Department of Islamic Development Malaysia, 'List of Approved Certified Bodies,' Halal Malaysia Official Portal, http://www.halal. gov.my/ckfinder/userfiles/files/cb2/26072018\%201\%20JUNE\%20\% 202018\%20 SENARAI\%20CB\%20TERKINI.pdf, accessed on 20 June 2018.

8 Lembaga Pengkajian Pangan Obat-obatan dan Kosmetika Majelis Ulama Indonesia, 'LPPOM MUI Regulation,' http://www.halalmui.org/images/stories/ pdf/LSH/LSHLN-LPPOM\%20MUI.pdf, accessed on 28 June 2018.

9 Abid, Sufyan, 'Muslim Consumers in a Globalized Market,' The Halal Frontier (2012): 93-94.

10 Agriculture and Agri-Food Canada, 'Global Pathfinder Report,' http://www.gov. $\mathrm{mb}$.ca/agriculture/market-prices-and-statistics/food-and-value-added-agriculturestatistics/, accessed on 12 June 2018. 
also stated that "through MABIMS (members of a regional association cluster comprising Brunei, Indonesia, Malaysia and Singapore) we have attained quite a bit, group effort with Brunei, Singapore and Indonesia." ${ }^{11}$

\section{METODOLOGY}

This study adopted both primary and secondary sources. The primary sources include statutes and judicial cases related to halal certification in Malaysia and other jurisdictions, while the secondary sources comprise of library materials (textbooks, journal articles, and newspapers), internet resources (i.e. online databases) and annual reports of JAKIM and MDTCC (Ministry of Domestic Trade, Cooperatives and consumerism).

\section{MALAYSIA}

Malaysia has projected a plan to be a halal hub by the year of $2020 .^{12}$ In responding to the vision, the government is trying to set Malaysia as an example for other countries in the distribution, production and promotion of products and services. ${ }^{13}$ Though Malaysia's halal certification mechanism is internationally recognized right now, it is updated continuously by Jabatan Kemajuan Islam Malaysia (JAKIM). ${ }^{14}$ Apart from that Brunei and Indonesia have incorporated some specific provisions on halal in their legislative framework. Actually strong regulatory frameworks only ensure halal products are properly certified and can expand more of the halal market around the world. ${ }^{15}$ Halal certification and verification mechanism have become a business entity all over the world for the enhancement of the halal industry.

11 Astro Awani, 'Malaysia Eyes New Progress in Regionalizing Halal Standards,' http://english.astroawani.com/business-news/malaysia-eyes-new-progressregionalising-halal-standards, accessed on 12 July 2018.

12 Rezai, G., Mohamed, Z. A., Shamsudin, M. N., \& Chiew, F. C., 'Concerns for Halalness of Halal-Labelled Food Products Among Muslim Consumers in Malaysia: Evaluation of Selected Demographic Factors,' Economic and Technology Management Review, vol. 4 (2009): 65-73.

13 Soraji, A. J., Awang, M. D., \& Yusoff, A. N. M., 'Malaysia Halal Trust: Between Reality and Challenges,' International E-Journal of Advances in Social Sciences, vol. 3, no. 7 (2017): 197-204.

14 'The Halal Journal: An Overview,' http://www.journal.com/artman/publish/ article_9.shtml., accessed on 12 July 2018.

15 Backhouse, C. J., \& Mohamad, N., 'A Framework for the Development of Halal Food Products in Malaysia,' (Proceedings of the International Conference on Industrial Engineering and Operations Management, Bali, Indonesia, 7-9 January 2014), 693-702. 
That was the driving force that encouraged the Malaysian authority to promulgate laws as well as specific rules and regulations on this matter. It paved the way for Malaysia to provide halal food with national and international jurisdictions which are highly recognized in the global market. ${ }^{16}$ The first legislative initiative was taken in the Trade Description Order 1975 (hereafter termed as TDO 1975). The use of false halal labeling and halal sign is a punishable offense under this law (Trade Description Order, 1975). Another initiative was in 1982, the Prime Minister's Department under the Islamic Affairs Division established a committee on the assessment of food, drinks and goods which are consumed by Muslims. ${ }^{17}$ This committee is responsible for inspecting and introducing awareness together with the halal food manufacturers, suppliers and traders. At the same time, the Malaysian government made a regulation that all meat (beef, mutton, veal and poultry) imported to Malaysia must have halal certification and such meat should be processed only from meat plants approved by the Islamic Affairs Division of the Prime Minister's Department and the Department of Veterinary Services, Malaysia. After that, the Islamic Affairs Department dispersed from the Prime Minister's Department and further action were continued by some new agencies known as Islamic Development Department of Malaysia (JAKIM) and Jabatan Agama Islam Negeri or known as the State Religion Departments (JAIN). The agencies have played an important role in the management of halal certification on behalf of the Malaysian government.

JAKIM is the core body that controls the administration of the Malaysian halal certification for halal products and it also creates policies which are then decided by the cabinet. JAKIM issues halal certification logos and approves products which strictly fulfill the halal requirements in accordance with the Shariah laws. These policies and standards are operated by JAKIM and JAIN for the purpose of halal certification. Apart from JAKIM, JAIN or State Islamic Religious Councils (MAIN) is also accepted bodies for halal certification. From the year 2009 onwards, a harmonized government of Malaysia halal logo was uniformly adopted by all states. Therefore, different halal logos from the states and bodies of certification were no longer apply. At that time, there are 67 foreign certification bodies that have been recognized by JAKIM. ${ }^{18}$ It will certify the procedure in Malaysia and for exporting; JAIN

16 Muhammad, N. M. N., Isa, F. M., \& Kifli, B. C., 'Positioning Malaysia as HalalHub: Integration Role of Supply Chain Strategy and Halal Assurance System,' Asian Social Science, vol. 5/7 (2009): 44.

17 Riaz, M. N., \& Chaudry, M. M., Halal Food Production (n.p.: CRC Press, 2003).

18 Management Division, Department of Islamic Development Malaysia, 'List of Approved Certified Bodies.' 
will issue certificates for the specific states only with the same halal logo. For the purpose of synchronization and coordination, JAKIM is working closely with Standards and Industrial Research Institute of Malaysia (SIRIM) and Department of Standard Malaysia (DSM) for the development of Malaysian halal food standards. In this respect, Malaysian halal certificate is issued by the government only. On the other hand, Islamic organizations are authorized to certify products in other countries. Meanwhile, JAKIM has developed its own halal manual procedures for the purpose of applying, auditing and monitoring halal certification measures. The principal purpose of halal certification by a recognized certification organization is to ensure a product is halal for Muslim consumers. Another purpose of JAKIM is to work as an implementation authority that imposes lawful provisions, operational principles and strategies for halal business in compliment with the halal regulations.

In 2011, the new Trade Description Act of 2011 was introduced. After the amendments of Trade Description Act 2011 (TDA 2011), JAKIM was authorized to do enforcement activities against any business holder or individuals who are abusing the halal logo in their products. Malaysia has to expand its legal provisions. The laws are sufficient and have been developed from time to time and are applicable throughout the country. The TDA 1972 along with its order Trade Description (Use of Expression Halal) Order 1975 and the Trade Description (Making of Food) Order 1975 are the main legislations to govern halal issues. The objectives of TDA 1972 as mentioned earlier include prohibiting misdescription of food and goods in the course of trade and business and forbidding the creation of deceitful or misrepresentative statements of any services or goods as the main objective of the order is to provide a detailed process to regulate halal issues. The amendments of TDA and TDO 2011 have brought main changes to the halal certification laws in this country. The Acts insert the specific provisions to administer halal issues and an order describes the procedure to deal with halal matters.

Equally, JAKIM and Ministry of Domestic Trade, Co-Operatives and Consumerism (MDTCC) have also halal regulated power; by virtue of the said Act and are authorized to enforce halal issues. However, Act 2011 gives them the power to govern halal issues but they are not fully exercising the enforcement power. It may be perceived here that the laws regulating halal certification as they exist today in Malaysia are quite adequate to deal with halal matters. However, as new problems arise in the case of enforcement of halal laws, there will always be a need for some reform or coordination of the authorities in terms of effective enforcement of halal issues to meet developing and often unexpected problems. 


\section{ADVANCEMENT OF HALAL CERTIFICATION IN INDONESIA}

Indonesia is situated in the SoutheastAsian region. It is the world's largest Muslim populated country. ${ }^{19}$ Currently, the world Muslim population is estimated to be 1.6-1.8 billion (about one-fifth of the total world population). In Indonesia, about $88 \%$ of the population are Muslims. ${ }^{20}$ Java, Sumatra, Kalimantan, West Nusa Tenggara, Sulawesi and North Maluku are the Muslim dominated areas. Having this huge number of Muslim community gives Indonesia a different view from other nations in terms of governing the whole nation together with halal life. The entire national life of Indonesia has enormously been influenced by Islamic beliefs. As a result, people are accustomed to Islamic commands. With this condition, the Indonesian government is responsible to its citizens to guarantee the halal products for consumption and use; this is also derived from the Indonesian constitution (1945). The obligation is contained in the form of legal certainty that covers the halal status of all products either to those useable, consumed or utilized by the society.

In 2010, the worth of global halal food market was around US\$651 billion and it is expected to go up to the US\$.21 trillion in 2015. Indonesia alone contributes US\$78.5 billion of the halal market. ${ }^{21}$ It is considered to be the biggest halal market of food products in Asia. Although Indonesia is the largest Muslim country in the world, national concerns for halal food started only in 1989, after which certification activities increased rapidly due to awareness and demand of Muslim people. ${ }^{22}$ The Indonesian Council of Ulama (Majelis Ulama Indonesia) is a well-known organizing body that deals with halal matters and issues halal certificate and label for halal food. The aim of the body is to develop a standard auditing system, supervise certification process, create awareness about the importance of halal products among the consumers and disseminate comprehensive and exact information as well as products and various related aspects. ${ }^{23}$

19 BBC News, 'Indonesia Country Profile: Overview,' http://www.bbc.com/news/, accessed on 12 August 2018.

20 Pew Research Center, 'Muslim Population of Indonesia,' http://www.pewforum. org/2010/11/04/muslim-population-of-indonesia/, accessed on 12 August 2018.

21 Ratanamaneichat, C., \& Rakkarn, S., 'Quality Assurance Development of Halal Food Products for Export to Indonesia,' Europe, vol. 64/4 (2013): 66-6.

22 Lembaga Pengkajian Pangan Obat-obatan dan Kosmetika Majelis Ulama Indonesia, 'LPPOM MUI Regulation,' http://www.halalmui.org/muil4/ index. php/main/go_to_section/4/33/page/1, accessed on 2 August 2018.

23 Lembaga Pengkajian Pangan Obat-obatan dan Kosmetika Majelis Ulama Indonesia, 'Visi dan Misi,' http://www.halalmui.org/muil4/ index.php/main/go_ to_section/3/32/page/1, accessed on 1 August 2018. 
Therefore, supported by some Muslim scholars and academicians, LPPOM-MUI established the Assessment Institute for Food, Drugs, and Cosmetics (hereafter termed as AIFDC) on $6^{\text {th }}$ January 1989 in Jakarta, that works along with its Fatwa Commission to process certification and issue halal label. Its members are competent multi-disciplinary scientists, who specialize in chemistry, biochemistry, food science and technology, veterinary, agroindustry and so on. Getting this certificate is a pre-requisite for companies for putting a halal mark in their products. LPPOM-MUI has become a trusted certifier in Indonesia, which certifies the halal status of a product in accordance with Islamic law and this certification is issued based on the assessment and audit by LPPOM-MUI. Moreover, it has become a world halal center which disseminates information and provides a comprehensive solution. Their halal standard has already been accepted at the national and international levels.

\section{Influential Factors for Consumption of Halal Food in Indonesia}

There are five main factors which influence Indonesian Muslims to consume halal food. ${ }^{24}$ These are:

a. Awareness: The level of halal awareness among Muslim consumers is very strong in Indonesia. Halal is the first concern during their consumption as well as purchasing any type of food products, they express their concern for choosing a restaurant. In all aspects, they constantly place a high priority on the halal issue;

b. Governmental Role: The role of the Indonesian government is encouraging and regulating the spiritual conduct in the case of halal food consumption. Moreover, audacious application of Shariah codes and courageous role of religious leaders strengthen their decision to consume halal food as well as lead them to perform halal life style irrespective of where they reside in Indonesia.

c. Religiosity: It is another important component which is influenced by religious experiences and education background for halal consumption in Indonesia. There is a deep relation between the highest degree of religiosity and consumption of halal food.

d. Halal Label: Indonesian consumers are relying on halal labeled food. Therefore, the halal certificate from the Majlis Ulama Indonesia (MUI) is important to the consumers in case of food packaging.

24 Abdul, M., Ismail, H., Mustapha, M., \& Kusuma, H., 'Indonesian Small Medium Enterprises (SMEs) and Perceptions on Halal Food Certification,' African Journal of Business Management, vol. 7, no. 16 (2013): 1492-1500. 
e. Interested Group: Finally, individual norms and seeming behavioral patterns of advanced learning, middle-class earnings, housewives, and young groups of people make them more concerned about halal consumption.

\section{Halal Related Provisions under the Indonesian Laws}

In Indonesia, there are five main laws containing halal provisions, namely Decree of the Minister of Religious Affair about Guidelines and Procedures for Examination and Determination of Halal Food (Decree No.518, 2001); Decree of the Minister of Religious Affairs about the institute for halal food inspection-implementing Minister of Religious Affairs of the Republic of Indonesia (Decree No.519, 2001); Decree of the Minister of Agriculture about slaughtering and meat handling (Decree No.413, 1992); Law about food and Law about consumer protection (Act No.8, 1999).

\section{LPPOM-MUI Regulations to Govern Halal in Indonesia}

SK Director LPPOM-MUI on Registration Rule Cerol-SS23000; SK Director LPPOM-MUI about List Materials Not Critical (Halal Positive List of Materials); SK Director LPPOM-MUI about Conditions Product Grouping; SK Director LPPOM-MUI about Conditions of Use New Raw Materials / Alternative; SK Director LPPOM-MUI LPPOM about the Establishment of the Office of China; SK Director LPPOM-MUI about Category Product Company Registrant MUI Halal Certificate and Halal Certification Process MUI Based Materials and Critical Levels Difficulty halal search; SK Director LPPOMMUI about Halal Certification Information; SK Director LPPOM-MUI about Halal Certification Financing Regulations; SK Director LPPOM-MUI about Halal Certification Registration Rules Special Company Based in China; SK Director LPPOM-MUI on the Elimination of Fiscal Costs and Changes in Audit Honor Overseas; SK Director LPPOM-MUI about Status "In Process" Halal Certification Bodies Overseas; SK Director LPPOM-MUI about Halal Certification Rules Submitted By Distributor; SK Director LPPOM-MUI about Halal Logo; SK Director LPPOM about List of Materials Halal MUI; SK Director LPPOM-MUI about Halal Certification Registration for Product Based Production in China; SK Director LPPOM-MUI about Conditions of Halal Assurance System; SK Director LPPOM- MUI about Criteria Halal Assurance System in Manufacturing (LPPOM-MUI Regulation, 2014) above are the LPPOM-MUI Regulations to govern halal in Indonesia. 


\section{Recent Amendment of Halal Laws in Indonesia}

On the $25^{\text {th }}$ October 2014, the House of Representatives in Indonesia passed the Bill of Halal Product Guarantee Law (Act no.33). After more than six years of awaited legislative process, the Bill of Halal Product Guarantee (UndangUndang Jaminan Produk Halal-UU JPH), ordinarily known as the "Halal Law" came into existence. Upholding the constitutional mandate is the main reason behind the enactment of this new law which declared that the state is stimulated to provide the guarantees of its resident to perform their religious belief and worship. In addition to these, to guarantee everyone's belief, it is the state's obligation to make available the halal products for consumption and use. However, the products that are disseminated in the society are not all guaranteed halal. Therefore, based on the above-stated concerns, the Law of Halal Product Guarantee Act has been enacted. Similarly, by the ratification and enactment of the law of the Republic of Indonesia Number 33 in the year 2014 about Halal Product Assurance, that is the proof of constitutionally safeguard obligation. By this law, the general public may possibly eat and use any products satisfyingly. Furthermore, it has firmed up the significance for business objects of halal products. The scope of this Act is limited to food and beverages, pharmaceutical, cosmetic and leather goods exports with extremely strict provisions. ${ }^{25}$ The most significant provision of this Act is that within two years the government will formulate the implementation bills of the law and it has to be enforced with mandatory halal certification within five years after the promulgation of the law. ${ }^{26}$ The law requires the whole food products that are disseminated in Indonesia must be certified as halal by 2019 or else they must be acknowledged as non-halal. ${ }^{27}$

\section{Overview of the Lawmaking Progress}

The journey of halal law with the governmental submitting its first draft to the House in $2009 .{ }^{28}$ It was very flexible in nature. There is no mandatory obligation to use halal certification for food and beverages, pharmaceutical, cosmetics, chemical, biological and genetically modified products. Subsequently, in 2010, the second draft brought notable changes that imposed 'mandatory halal certification' instead of 'voluntary halal certification'. That draft mentioned

\footnotetext{
$25 \quad$ Art.1, Halal Product Certification Act 2014.

26 Art.65, Halal Product Certification Act 2014.

27 Art. 26, Halal Product Certification Act 2014.

28 Polishcosmetics, 'Indonesia: Law on Halal Product Guarantee,' http:// polishcosmetics.pl/2014-Indonesia-Law, accessed on 12 October 2018.
} 
that to get the halal certificate, the producer must register his or her products along with the halal label. In the case of non-halal products, it should have a non-halal label. The debate regarding halal law enactment was continued until 2013 with some agreement and disagreement. Finally, on $25^{\text {th }}$ September 2014, the House approved the Halal bill, which mainly laid down the mandatory halal certification for food and products, with the proposal of establishment of Halal Certification Body and Halal Audit Institution. In addition, Art.5 and 6 of said law specifically remarks that under the Ministry of Religious Affair (MoRA), the Halal Product Guarantee Agency (Badan Penyelenggara Jaminan Halal) will be established and it will be responsible for issuing a halal certificate and Fatwa from Majelis Ulama Indonesia. Sections 12 and 32 of Halal Product Certification Act 2014 gave the mandate to establish the Halal Verification Institute (Lembaga Pemeriksa Halal) for inspecting, examining, and verifying and testing halal parameters for the products and give recommendations which will be reported to MUI. Under Art. 14 and 15 Halal Verification Institute appoints halal auditors and who are responsible for the inspection of products. Art. 33 of the Halal Product Certification Act 2014 empowers the institution to deliver their decision to MUI.

\section{Most Important Provisions of New Halal Law in Indonesia}

The new Halal Law in Indonesia comprised the following most significant provisions, which are:

a. In terms of food and beverages, cosmetics, pharmaceutical, biological, chemical, and genetically modified products, halal is mandatory. Furthermore, convenient goods to be used or consumed by the general public or imported or circulated and traded in Indonesia's customs area should have a mandatory halal certificate as well. ${ }^{29}$

b. Halal products must be declared as halal according to Shariah laws. It is a collective work that makes a product completely halal. For example, raw materials, processing, storage, packaging, distribution, sales, and serving must be followed by halal guideline. ${ }^{30}$

c. The Implementation of the law must come to light within two years at the latest after the proclamation of the law. ${ }^{31}$

29 Art.1.1 and 4, Halal Product Certification Act 2014.

30 Art.1.3, Halal Product Certification Act 2014.

31 Art.65, Halal Product Certification Act 2014. 
d. Under the directive of the new law Halal Product Guarantee Agency is to be established that will be administered by the Ministry of Religious Affairs and will be in the authority for delivering halal certificates. ${ }^{32}$

e. To fulfil the mandatory halal certificate requirement on products that are distributed and traded in Indonesia, the government will provide five years' time for the achievement of the goal of the law. Besides, the government is trying to gradually develop the procedure. In the case of halal certification and verification of products, the raw materials of such products, manufacturing process, the location of production and facilities, packaging, storing distribution, and serving must done by proper authority. Under this law, halal screening must be ensured..$^{33}$

f. Every haram or non-halal food must bear "non-halal" label. ${ }^{34}$

g. According to the said law, once the halal certificate is secured, it will be valid for four years. ${ }^{35}$

h. The law provides criminal sanctions of imprisonment up to five years and penalty up to IDR two billion for companies which fail to maintain halal process after obtaining halal certification for its products; and imprisonment up to two years and penalty up to IDR two billion for anyone involved in the halal certification process who does not maintain confidentiality of information. ${ }^{36}$

\section{Halal Labeling Development in Indonesia}

It is perceived that the new halal law will be able to position Indonesia as the world's pioneer halal products and world halal. ${ }^{37}$ This new law focuses on halal labeling for the protection of Muslim consumers' rights. Some past bitter experiences have led Indonesia to enact the present law. Major incidents included the pig scare in 1998 and a Japanese company used a pork substance

\footnotetext{
32 Art.12 and 32, Halal Product Certification Act 2014.

33 Art.1.1, 17-22 and 25, Halal Product Certification Act 2014.

34 Art. 26, Halal Product Certification Act 2014.

35 Art. 42, Halal Product Certification Act 2014.

36 Art. 56-67, Halal Product Certification Act 2014.

37 Halal Focus, 'Brunei: MoRA Stands Firm on Halal Certification Process,' http:// halalfocus.net/brunei-mora-stands-firm-on-halal-certification-process/, accessed on 12 October 2018.
} 
for the enhancement of flavour in 2001. ${ }^{38}$ Statistics from MUI Food and Drug Analysis Agency (LPPOM-MUI) shows that of around 30,000 food products circulating in Indonesia, nearly $80 \%$ do not have an official halal certificate. ${ }^{39}$

\section{HALAL CERTIFICATION PROGRESS IN SINGAPORE}

Singapore is not a Muslim dominated country like Malaysia, Brunei and Indonesia. Muslims are one-seventh ${ }^{40}$ (Population Trends, 2015) of the total population and there are two major groups of Muslims - some of them are of Malay origin and some of them of Indian origin. According to the statistics, in Singapore there are approximately 497,317 Malay Muslims and 75,541 Indian Muslims combined with Pakistanis, Arabs and others.

In view of this matter, Majlis Ugama Islam Singapore (hereafter termed as MUIS) was established in $1968^{41}$ and was entrusted to deal with any matters related to halal certification services. It started by issuing the halal certificate from $1978^{42}$ and its halal certification mark is recognized not only in Brunei, Indonesia, Malaysia but also in the Gulf Cooperation Council countries. MUIS became more powerful and comprehensive in nature by virtue of the 1999's amendment of the Administration of Muslim Act (hereafter termed as AMLA), which serves Muslims and Muslim religious affairs and to constitute a council to advise on matters relating to Islam in Singapore and Shariah Court. In Singapore, MUIS is the sole authorized body that certifies all exported halal food and goods and approves halal organizations of exported countries.

In 2010, it hosted the third MUIS three-year plan for halal development that faithfully examined the products and maintained the spirit of religious law. By being rigorous, it guarantees the Muslim consumers' confidence in consuming

38 Nurish A., 'Halal Labeling: The Next Gold Miner,' http://www.thejakartapost. com/news/2014/02/28/halal-labeling-the-next-gold-mine.html, accessed on 2 October 2018.

39 David H., 'Most Local Food Not Officially Halal: MUI,' http://www.thejakartapost. com/news/2010/01/07/most-local-food-not-officially-halal-mui.html, accessed on 23 October 2018.

40 Singapore Department of Statistics, 'Publications and Papers/Population and Population Structure,' http://www.singstat.gov.sg/docs/library/publications_and_ papers/population_and_population_structure/, accessed on 12 October 2018.

41 Islamic Religious Council of Singapore, 'About MUIS,' http://www.muis.gov, accessed on 22 October 2018.

42 Islamic Religious Council of Singapore, 'Singapore Halal Certification,' http:// www.halal.sg/, accessed on 20 October 2018. 
and using MUIS certified products and services. This certificate is governed by the rules of Halal Quality Management System (hereafter termed as HalMQ).

In addition, the promising halal food industry with the availability of many halal-certified eateries has helped to foster social interaction between individuals from diverse racial, cultural and religious backgrounds. The halal enforcement mechanism is regulated by MUIS and other governmental bodies such as the Food Control Department, Ministry of Environment; the AgroVeterinary Authority, Ministry of National Development and the Commercial Crime Department, Ministry of Home Affairs. ${ }^{43}$

\section{Overview of the Singapore Halal Industry and Halal Certificate}

Geographically, Singapore is located in the very heart of Asia and is an important factor for the upcoming development of its halal Industry. Muslim consumers, business entrepreneurs and the government are tapping into the halal industry for the economic benefits of its state. The head of the halal certification strategic unit, MUIS (Islamic Religious Council of Singapore) said that due to the noticeable consciousness of the economic prospective of the halal industry, they are expecting this movement to continue and it is a rising demand from local Muslim consumers for halal food and the growing tourism industry. ${ }^{44}$ Taking into consideration of the amount of halal food consumption and its consumer expectation, it is essential to maintain halal value chain in Singapore. Product improvement, testing, consultancy along with trade will enhance the reliability of Singapore's halal brand stated by the Minister of Information, Communications and the Arts and work of all sectors in the supply chain can make sure strict halal compliance from farm to fork. ${ }^{45}$

Based on the abovementioned discussion, it is evident that Singapore is quite conscious about halal matters. The number of application for halal certification rate is $10 \%$ in every year and is expected to go upwards. Additionally, as per the statistics of 2000 to 2010 , the total number of halal certified premises have increased to almost fivefold as certified by MUIS, from 533 to 2,650 in which 400 are food manufacturing companies which is expected to increase to 5000 in 2015. ${ }^{46}$ This will also increase halal certified food products. Furthermore,

43 Riaz, M. N., \& Chaudry, M. M., Halal Food Production.

44 Marshall Cavendish, 'Singapore Halal Directory,' http://www.micemalaysia.com/ indprof/SHD/SHD\%20 1213, accessed on 12 October 2018.

45 Marshall Cavendish, 'Singapore Halal Directory.'

46 Flanders Investment \& Trade, 'Halal Food Sector in Singapore,' https:// www.flandersinvestmentandtrade.com/export/sites/trade/files/market studies/817141210035723/817141210035723_1.pdf, accessed on 12 October 2018 . 
the annual report published by MUIS in 2011 indicated that halal certification increased from 19,994 to 22,999 in 2013 and this indicated 13\% progress. $^{47}$

\section{Related Provisions under Singaporean Laws}

Subject to the amendment made to AMLA (Administration of Muslim Act) the Majlis Ugama Islam Singapore (MUIS) was given the authority to regulate, promote and enhance the halal food industry. Section 2 of the said Act has the terms "halal" and "halal certificate" which are described as follows:

$i$ "Halal, in relation to any product, service or activity, means the requirements of the Muslim law are complied with in the production, processing, marketing, display or carrying out, as the case may be, of that product, service or activity",

ii "Halal certificate, in relation to any product, service or activity, means a certificate to the effect that the requirements of the Muslim law are complied with in the production, processing, marketing, display or carrying out, as the case may be, of that product, service or activity".

In addition, Part VA, Section 88(A) of AMLA provides the details on halal certification related matters which among others empowering the Majlis Ugama Islam Singapore (MUIS):

i. "The Majlis may issue halal certificates in relation to any product, service or activity and regulate the holders of such certificates to ensure that the requirements of the Muslim law are complied with in the production, processing, marketing or display of that product, the provision of that service or the carrying out of that activity",

ii. "The Majlis may, in issuing a halal certificate, impose such condition as it thinks fit and may at any time vary, remove or add to such condition",

iii. "Any person who, without the approval of the Majlis-

a) Issues a halal certificate in relation to any product, service or activity; or

47 Islamic Religious Council of Singapore, 'Annual Report,' http://www.muis.gov. sg, accessed on12 October 2018. 
b) Uses any specified halal certification mark or any colourable imitation thereof, shall be guilty of an offence and shall be liable on conviction to a fine not exceeding \$10,000 or to imprisonment for a term not exceeding 12 months or to both",

iv. "The Majlis may, in granting approval to any person to issue any halal certificate or to use any specified halal certification mark, impose such condition as it thinks fit and may at any time vary, remove or add to such condition",

v. The Majlis may revoke or suspend its approval granted to any person to issue any halal certificate or to use any specified halal certification mark if that person fails to comply with any condition imposed under subsection (6)",

vi. "Any person aggrieved by any decision of the Majlis made under this section may appeal to the Minister whose decision shall be final" (Administration of Muslim Act revised on 2009).

\section{Leading Case Laws of Halal Certificate in Singapore}

Public Prosecutor $v$ Angliss Singapore Pte Ltd ${ }^{48}$ was the first reported case in Singapore regarding illegal use of halal certification mark on food products.

\section{Facts and Issues in Brief}

A certification officer of the halal certification strategic unit of MUIS carried out an investigation in the food preparation area of a canteen located at Seagate Technology International Building, 16 Woodlands Loop on $4^{\text {th }}$ August 2005. In the course of the examination, he found a few sealed packets of chicken nuggets carrying the brand "Dewfresh" with the specified halal certification mark of MUIS imprinted on the packaging. The said packaging also contained printed words stating that the said product was imported and packed by Angliss Singapore Pte Ltd of 232 Pandan Loop Singapore 128420 (defendant company). There was at the actual time, no halal certification mark issued by MUIS with respect to that food product.

In addition, another officer from MUIS found ten packets "Dewfresh" chicken nuggets with the same halal certification mark of MUIS and they were sold of the Carrefour Hypermarket at Suntec City Mall on August 11 ${ }^{\text {th }}, 2005$.

48 Public Prosecutor v Angliss Singapore Pte Ltd [2006] SGDC 70. 
The packets of the said product matched the ones earlier found at Seagate Technology canteen.

Based on these facts, on August $11^{\text {th }}$, 2005, MUIS wrote this matter to the defendant company and the defendant company self-confessed to this in writing and apologized for using the halal certification mark without the approval of MUIS. The investigations revealed in the records of MUIS said the product was not certified by MUIS to be halal, that is, it did not meet the requirements of Muslim law for sale in Singapore at the time. The defendant company had packed or caused to pack the chicken nuggets in plastic bags containing the MUIS halal certification mark and imported them into Singapore for sale and had thereby breached Section 88A(5)(b) AMLA (Act no.27, revised on 2009).

\section{The Applied Law}

After analyzing the facts and taking into consideration the Prosecution's submissions, the Court reached in this decision that the defendant was guilty under Section $88 \mathrm{~A}(5)(\mathrm{b})$ that provides a maximum fine of $\$ 10,000$ or 12 -month imprisonment or both. However, as a prosecution against a corporation the only sentencing option available to the Court is to impose a fine. So, based on the facts of the Case, the court imposed a fine of $\$ 9,000$ on the defendant company. $^{49}$

\section{Reasons for the Rationale}

There was a number of provoking factors in this case. First of all, the infringement was not a minor one. The defendant company had sold their products in a large market and people believed that products were validly certified by MUIS; actually, it was a misleading and the company was charged only for selling one packet products but there were more packets for sale. Moreover, the defendant company had been importing such products into Singapore for the last two years and had conceded that it had at least on another earlier occasion illegally passed them off as having MUIS certification. Lastly, the consequence of such offenses is the violation of public interest. The defendant was well aware of the laws on the use of halal certification marks (SGDC 70). As a result, the defendant filed an appeal to the High Court Angliss Singapore Pte Ltd v Public Prosecutor. ${ }^{50}$

49 Public Prosecutor v Angliss Singapore Pte Ltd [2006] SGDC 70.

50 Public Prosecutor v Angliss Singapore Pte Ltd [2006] SGDC 70. 
The High Court said that the District court pronounced judgment on the basis of the violation of Section 88A (5) (b) of AMLA together with the principle of public interest. In this case the appellant pleaded guilty for having illegally affixed a specified halal certification mark on August $11^{\text {th }} 2005$ without the approval of the Majlis Ugama Islam Singapore on a packet of chicken nuggets imported by the appellant into Singapore, contrary to Section 88A (5) (b) of the Administration of Muslim Law Act. The learned district judge imposed a fine of $\$ 9,000$ after hearing the appeal, the fine was reduced to $\$ 2,000$.

In this case, the appellant pleaded guilty. Thus courts in Singapore should adopt the principle that if anyone pleads guilty then a maximum prescribed sentence should be meted out. In the above case, this principle was considered and explained on the grounds of decision (SGHC 155).

Important issues were pointed out in this case along with the reason for amendment of AMLA:

"The constructive purpose of the halal certification regime is to ensure that Muslim consumers do not mistake non-halal for certified halal food products. While 88A(5)(b) of the AMLA renders any omission to seek MUIS's approval for the use of the halal certification an offence, it would be pertinent to take into account that the negligent of the appellant in complying with the regulation set out in the AMLA .......",

"Having perused the Parliamentary debates during the Second Reading of the Administration of Muslim Law (Amendment) Bill on 30 June 1998 (Singapore Parliamentary Debates, Official Report (30 June 1998) vol 69 at cols 440-502 ("Parliamentary Debates") and the Report of the Select Committee on the Administration of Muslim Law (Amendment) Bill (Bill No 18/98) (10 February 1999), I find the Minister explicitly stated that the regulation and prosecution of halal certification was handed over to MUIS in recognition of the fact that as MUIS was already doing much of the work in relation to these areas, it made far more practical and symbolic sense for MUIS to administer this area of Muslim affairs exclusively. MUIS has also been advising on halal matters as it is an issue of concern to the Muslim public. The proposed amendment will give MUIS the sole authority to advise on halal matters, to regulate halal certification and to issue halal certificates itself. These amendments will strengthen MUIS 'position as the authority on Muslim affairs in Singapore" (SGHC 155). 


\section{HALAL DEVELOPMENT IN BRUNEI}

Brunei Darussalam is a Southeast Asian country on the north-western coast of with an estimated inhabitant of 428,000 and $82 \%$ of the total population professes to Islamic religion, 7\% Buddhism and 3\% Chinese religion. The remaining are aboriginal groups and immigrants. Constitutionally Brunei is a Sultanate governing republic and Islam is the state religion (Part II of the Constitution of Brunei Darussalam).

"The religion of Brunei Darussalam shall be the Muslim religion according to the Shafi'i sect of that religion: Provided that all other religions may be practiced in peace and harmony by the person professing them in any part of Brunei Darussalam. "

Brunei plans to create a bio-innovation corridor with an objective to maintain the development of halal-certified industries with a specific focus on halal food products, cosmetics, pharmaceuticals, biotechnology and logistics. The value of the currently estimated halal industry is worth more than $\$ 1$ trillion a year and considering that, the government of Brunei has a desire to place itself at the center of the fast-growing halal products industry. ${ }^{51}$

The emphasis on halal is taking a centerpiece and indeed growing. ${ }^{52}$ It is moving into the mainstream, affecting and changing how business is being done. Being a strict Islamic nation Brunei is more rigorous compared to other countries. The main authorized body for the halal certification is the Islamic Religious Council of Brunei Darussalam. ${ }^{53}$ At present Brunei open halal certification label serves as a platform for its local Small and Medium Enterprises (SMEs) to grow. ${ }^{54}$

$51 \quad$ Enda Mullen, 'UK: Brunei’s Halal Industry Centre Targets Midland Businesses,' HalalFocus.net: Daily Halal Market News, http://halalfocus.net/uk-bruneis-halalindustry-centre-targets-midland-businesses/, accessed on 12 October 2018.

52 Cheng, P. L. K., \& Low, K., 'The Brand Marketing of Halal Products: The Way Forward,' The Icfai University Journal of Brand Management, vol. 5, no. 4 (2008): 37-50.

53 ASEAN-Japan Centre, 'Brunei Halal Certification,' http://www.asean.or.jp, accessed on 12 October 2018.

54 Ismail, A. B. H., \& Laidey, N. M., 'Clients, Consumers and Customers' Perception on Halal Implementation in Small and Medium Enterprises (SMEs) in Brunei,' The International Journal of Business \& Management, vol. 2, no. 10 (2014): 35. 


\section{Brunei Halal Certificate}

Administratively, for the interpretation of 'halalness' for producers, restaurateurs and food outlets in service around the country, the Sultanate has more consciousness to make sure strict devotion is applied to the supply of halal products. ${ }^{55}$ The government is taking a proactive approach by giving a directive to restaurants, manufacturers and all sectors to apply for halal certification for the benefit of the country's Muslims.

The Jabatan Hal Ehwal Syariah (Ministry of Religious Affairs) (hereafter termed as JHES) is the authorized body to handle halal certification. Under this department, there is Halal Food Control Division. ${ }^{56}$ It is the authoritative organization that controls the country's halal diet. In these respect, it tries to confirm the halal meat products, that raw meat sold to the public is halal, enforce the Halal Meat Act and the Order of the Halal Certificate and Halal Label 2005. ${ }^{57}$ In addition, the entry of meat to be marketed in the country must bear certification from the centers that recognize halal slaughter by the Islamic Religious Council of Brunei. In addition, it also exercises supervision of the halal auditing to the applicant that wishes to obtain a certificate or permit previously granted halal certification of the Brunei Islamic Religious Council (Halal Certification).

Furthermore, to enforce halal certification, the Brunei government created a committee consisting of officers from the Islamic Religious Council, State Judiciary, Agriculture Department, Ministry of Industry and Primary Resources, Ministry of Health, Islamic Judicial, Halal Food Control Division and Shariah Affairs at the Ministry of Religious Affairs. The responsibilities of these officials are to manage, supervise or choose other officers to carry out inspection and enforcement duties which will cover every aspect of food production, preparation and even sales. Besides, these inspection officers will be authorized to check on numerous premises to ensure that all the ingredients are halal and that the area where foods are prepared is acceptable according to the guideline. If any food is suspicious, then the officers can send it to the laboratories. ${ }^{58}$

55 Ismail, A. B. H., \& Laidey, N. M., 'Clients, Consumers and Customers' Perception on Halal Implementation in Small and Medium Enterprises (SMEs) in Brunei,' 35.

56 Halal Research Council, 'Guideline for Halal Certification, the Religious Council Brunei Darussalam,' http://www.halalrc.org/, accessed on 12 October 2018.

57 Halal Research Council, 'Guideline for Halal Certification, the Religious Council Brunei Darussalam.'

58 Halal Research Council, 'Guideline for Halal Certification, the Religious Council Brunei Darussalam,’ http://www.halalrc.org/, accessed on 12 October 2018. 


\section{Halal Governing Laws in Brunei}

Similarly to other countries such as Malaysia and Indonesia, Brunei has placed rules and regulations that govern halal certification. These are as follows:

\section{a) Halal Meat Act}

This Act sets out provisions for the supply and importation of halal meat, which ensures that the meat is fit for Muslim consumption. The Act provides for the establishment of a Board for issuing halal import permits and for an inspection committee and defines their internal composition. Furthermore, the Act provides for the procedures and requirements for obtaining a halal import permit; requirements for the supply of local halal meat; powers of the inspection committee to inspect any slaughtering center at any time; offences and penalties; rule making powers of the Minister; etc. (Halal Meat Act Amendment on 2010 and Revised on 2014).

\section{b) Halal Meat Rules, 2008 (Act no. 69)}

\section{c) Halal Certificate and Halal Label Order, 2005}

The objective of Halal Certificate and Halal Label Order 2005 is to ensure all food and drink to be consumed by Muslim are 100\% halal. According to Chapter 4 (1) under the Halal Label Order, any Muslim or non-Muslim business owner is qualified to apply for certification, as long as they employ at least two halal food supervisors at the premises. The halal food supervisor should also be Muslim and it has to be approved by the Islamic Religious Council that he or she is fit for that position. To be qualified they have to possess adequate knowledge of halal and haram (food ingredients, equipment utilized at the business premises (Act no.39).

\section{d) Guidelines for Halal Certification}

The purpose of the guidelines for Halal Certification is to make clear the necessities to be fulfilled in order to get the halal certificate and halal permit issued by the Majlis Ugama Islam Brunei Darussalam. These include the place of business to be set up and implement halal procedures that meet the Brunei Darussalam Standard for Halal Food PBD 24: 2007, followed by the application and granting of the halal certificate and halal label. The certification 
process includes adequacy, compliance and any follow-up audits by appointed certified auditors..$^{59}$

\section{e) Standard for Halal Food}

The Standard for Halal Food is to fulfil the existing needs for the local halal food industry. It covers the general guiding principles for the manufacture, production, management, circulation and storing of halal food in Brunei Darussalam.

For the enforcement and carrying out of the law, it is extended to government agencies such as the Royal Brunei Police Force and Ministry of Industry and Primary Resources, under the Ministry of Religious Affairs. ${ }^{60}$

\section{Halal Development in Brunei}

In Brunei, the government created Brunei Halal Brand which is under the governmental framework. It was introduced by the Ministry of Industry and Primary Resources together with the cooperation of the Brunei Islamic Religious Council, Ministry of Religious Affairs and the Ministry of Health. ${ }^{61}$ This initiative was developed by the government of Brunei Darussalam to create a new commercial image for halal food. In Brunei for food products, Halal Brand is used to certify the food that is in good quality and halal. This vision includes both products; local as well as non-local. Additionally, in 2013 Brunei made mandatory provisions to obtain halal certification and halal label for general restaurants, food premises and food or drink manufacturing premises that serve or produce halal food and drinks. ${ }^{62}$

59 Halal Research Council, 'Guideline for Halal Certification, the Religious Council Brunei Darussalam.'

60 Instituto Halal, 'Estandar halal de Brunei,' http://www.institutohalal.com/blog/ estandar-halal-de-brunei/, accessed on 12 October 2018.

61 Brunei Halal, Ministry of Industry and Primary Resources, http://www.mprt.gov. bn/sitepages/halal\%20industry\%20innovation\%20centre.aspx., accessed on 12 October 2018.

62 Kon J., 'New Policy on Mandatory Halal Certification for Eateries, Manufacturers,' http://bruneiembassy.be/new-policy-on-mandatory-halal-certification-foreateries-manufacturers/, accessed on12 October 2018. 
Besides, the halal status of food products needs to be reviewed regularly to ensure the Muslims that their food fulfils the requirements of halal. ${ }^{63}$ Having a halal certificate and halal logo attached to food products is not enough for Muslims to be satisfied with the halal status of goods they consume. What is more important is that relevant authorities monitor and test consumables that have been granted the halal certificates and logos from time to time.

\section{CONCLUSION}

The above discussion indicated that Malaysia, Indonesia, Brunei and Singapore are noticeably concerned about halal development. Halal significantly affects their national economy. Each country is trying to develop and strengthen their halal certification procedure by implementing advanced rules and regulations in their halal legal system. All the above mentioned countries' governments are trying to make sure that they can provide $100 \%$ halal food products to their Muslim consumers.

There are some initiatives taken by these countries which are different from each other's. For example, Indonesia enacted Halal Law for their country's benefits. This law imposes a mandatory obligation to food producers, manufacturers and restaurant owners to use the halal certificate on all food and products. Besides that, it also contains a compulsory provision to use the non-halal mark for non-halal food and products. It paves the way for the government to ensure all products are genuinely halal. In addition, said Act proposes to create a Halal Certification Body and Halal Audit Institution to monitor halal certification procedures. It has the authority to issue the halal certificate under the supervision of Majelis Ulama Indonesia. Furthermore, this institution enjoys certain powers to examining, verifying and testing halal factors for food and products and is also entitled to inspect complaints. By implementing this law, the Indonesian government is trying to disseminate halal food and products to the whole country.

On the other hand, Singapore being a non-Muslim country is concerned about halal development for the benefit of their minority Muslim population. Though AMLA, the Singaporean government has delegated halal enforcing power to MUI. To enhance halal enforcement mechanism, Singapore government has strengthened MUI's halal executing power though the last amendment of AMLA. Not only government initiative but judicial intervention

63 Waqiuddin R., 'Review Halal Labels Regularly,' http://m.bt.com.bn/frontpagenews-national/2014/06/06/having-halal-certificate-logo-attached-food-product, accessed on 12 October 2018. 
also plays a significant role in the development of halal matters in Singapore. Some reported cases have entertained specific section of AMLA regarding halal certification.

Furthermore, Brunei as an Islamic state expands its halal regulations and its government is very rigid for the execution of halal. Brunei Halal Brand is also recognized worldwide. To ensure 100\% halal food products around the whole country, the government is working progressively. Considering all the facts it can be concluded that the above mentioned four countries are gradually developing their halal certification procedure and their aims are to be examples for each other. In addition, they are trying to hold the best position in the global halal market. In all aspects, they are focusing on the effective implementation of halal execution whereby these countries can achieve their goal in terms of halal certification.

\section{REFERENCES}

Abdul, M., Ismail, H., Mustapha, M., \& Kusuma, H., 'Indonesian Small Medium Enterprises (SMEs) and Perceptions on Halal Food Certification,' African Journal of Business Management, vol. 7, no. 16 (2013): 14921500 .

Abid, Sufyan, 'Muslim Consumers in a Globalized Market,' The Halal Frontier (2012): 93-94.

Agriculture and Agri-Food Canada, 'Global Pathfinder Report,' http://www. gov.mb.ca/agriculture/market-prices-and-statistics/food-and-valueadded-agriculture-statistics/, accessed on 12 June 2018

ASEAN-Japan Centre, 'Brunei Halal Certification,' http://www.asean.or.jp, accessed on12 October 2018.

Astro Awani, 'Malaysia Eyes New Progress in Regionalizing Halal Standards,' http://english.astroawani.com/business-news/malaysia-eyes-newprogress-regionalising-halal-standards, accessed on 12 July 2018.

Backhouse, C. J., \& Mohamad, N., 'A Framework for the Development of Halal Food Products in Malaysia,' (Proceedings of the International Conference on Industrial Engineering and Operations Management, Bali, Indonesia, 7-9 January 2014), 693-702.

BBC News, 'Indonesia Country Profile: Overview,' http://www.bbc.com/ news/, accessed on 12 August 2018.

Brunei Halal, Ministry of Industry and Primary Resources, http://www.mprt. gov.bn/sitepages/halal\%20industry\%20innovation\%20centre.aspx, accessed on 12 October 2018. 
Cheng, P. L. K., \& Low, K., 'The Brand Marketing of Halal Products: The Way Forward,' The Icfai University Journal of Brand Management, vol. 5, no. 4 (2008): 37-50.

David H., 'Most Local Food Not Officially Halal: MUI,' http://www. thejakartapost.com/news/2010/01/07/most-local-food-not-officiallyhalal-mui.html, accessed on 23 October 2018.

Enda Mullen, 'UK: Brunei’s Halal Industry Centre Targets Midland Businesses,' HalalFocus.net: Daily Halal Market News, http://halalfocus.net/ukbruneis-halal-industry-centre-targets-midland-businesses/, accessed on 12 October 2018.

Evangelia Komitopoulou, 'The Growth of the Halal Market and the Role of Halal Certification,' http://www.sgs.com/en/news/2014/10/the-growthof-the-halal-market-and-the-role-of-halal-certification, accessed on 21 December 2018.

Flanders Investment \& Trade, 'Halal Food Sector in Singapore,' https:// www.flandersinvestmentandtrade.com/export/sites/trade/files/market studies/817141210035723/817141210035723_1.pdf, accessed on $1 \overline{2}$ October 2018.

Halal Focus, 'Brunei: MoRA Stands Firm on Halal Certification Process,' http://halalfocus.net/brunei-mora-stands-firm-on-halal-certificationprocess/, accessed on 12 October 2018.

Halal Research Council, 'Guideline for Halal Certification, the Religious Council Brunei Darussalam,' http://www.halalrc.org/, accessed on 12 October 2018.

Instituto Halal, 'Estandar halal de Brunei,' http://www.institutohalal.com/ blog/estandar-halal-de-brunei/, accessed on 12 October 2018.

Islamic Religious Council of Singapore, 'About MUIS,' http://www.muis.gov, accessed on 22 October 2018.

Islamic Religious Council of Singapore, 'Annual Report,' http://www.muis. gov.sg, accessed on12 October 2018.

Islamic Religious Council of Singapore, 'Singapore Halal Certification,' http:// www.halal.sg/, accessed on 20 October 2018 .

Ismail, A. B. H., \& Laidey, N. M., 'Clients, Consumers and Customers' Perception on Halal Implementation in Small and Medium Enterprises (SMEs) in Brunei,' The International Journal of Business \& Management, vol. 2, no. 10 (2014): 35. 
Kon J., 'New Policy on Mandatory Halal Certification for Eateries, Manufacturers,' http://bruneiembassy.be/new-policy-on-mandatoryhalal-certification-for-eateries-manufacturers/, accessed on 12 October 2018.

Lembaga Pengkajian Pangan Obat-obatan dan Kosmetika Majelis Ulama Indonesia, 'LPPOM MUI Regulation,' http://www.halalmui.org/images/ stories/pdf/LSH/LSHLN-LPPOM\%20MUI.pdf, accessed on 28 June 2018.

Lembaga Pengkajian Pangan Obat-obatan dan Kosmetika Majelis Ulama Indonesia, 'LPPOM MUI Regulation,' http://www.halalmui.org/mui14/ index.php/main/go_to_section/4/33/page/1, accessed on 2 August 2018.

Lembaga Pengkajian Pangan Obat-obatan dan Kosmetika Majelis Ulama Indonesia, 'Visi dan Misi,' http://www.halalmui.org/mui14/ index.php/ main/go_to_section/3/32/page/1, accessed on 1 August 2018.

Management Division, Department of Islamic Development Malaysia, 'List of Approved Certified Bodies,' Halal Malaysia Official Portal, http://www.halal.gov.my/ckfinder/userfiles/files/cb2/26072018\%20 1\%20JUNE\%20\%202018\%20SENARAI\%20CB\%20TERKINI.pdf, accessed on 20 June 2018.

Marshall Cavendish, 'Singapore Halal Directory,' http://www.micemalaysia. com/indprof/SHD/SHD\%20 1213, accessed on 12 October 2018.

Marzuki, S. Z. S., Hall, C. M., \& Ballantine, P. W., 'Measurement of Restaurant Manager Expectations Toward Halal Certification Using Factor and Cluster Analysis,' Procedia-Social and Behavioral Sciences, vol. 121 (2014): 291-303.

Mohamed, Z., Shamsudin, M. N., \& Rezai, G., 'The Effect of Possessing Information About Halal Logo on Consumer Confidence in Malaysia,' Journal of International Food \& Agribusiness Marketing, vol. 25 (2013): 73-86, sup1.

Muhammad, N. M. N., Isa, F. M., \& Kifli, B. C., 'Positioning Malaysia as Halal-Hub: Integration Role of Supply Chain Strategy and Halal Assurance System,' Asian Social Science, vol. 5/7 (2009): 44.

Nurish A., 'Halal Labeling: The Next Gold Miner,' http://www.thejakartapost. com/news/2014/02/28/halal-labeling-the-next-gold-mine.html, accessed on 2 October 2018.

Pew Research Center, 'Muslim Population of Indonesia,' http://www. pewforum.org/2010/11/04/muslim-population-of-indonesia/, accessed on 12 August 2018. 
Polishcosmetics, 'Indonesia: Law on Halal Product Guarantee,' http:// polishcosmetics.p1/2014-Indonesia-Law, accessed on 12 August 2018.

Ratanamaneichat, C., \& Rakkarn, S., 'Quality Assurance Development of Halal Food Products for Export to Indonesia,' Europe, vol. 64/4 (2013): 66-6.

Rezai, G., Mohamed, Z. A., Shamsudin, M. N., \& Chiew, F. C., 'Concerns for Halalness of Halal-Labelled Food Products Among Muslim Consumers in Malaysia: Evaluation of Selected Demographic Factors,' Economic and Technology Management Review, vol. 4 (2009): 65-73.

Riaz, M. N., \& Chaudry, M. M., Halal Food Production (n.p.: CRC Press, 2003).

Said, M. M., \& Elangkovan, K., 'Halal Label and the Ethics of Business: An Analytical View from Producers,' Australian Journal of Basic and Applied Science, vol. 7, no. 6 (2013): 613-621.

Singapore Department of Statistics, 'Publications and Papers/Population and_Population Structure,' http://www.singstat.gov.sg/docs/library/ publications_and_papers/population_and_population_structure/, accessed on $1 \overline{2}$ October 2018.

Soesilowati, E. S., 'Business Opportunities for Halal Products in the Global Market: Muslim Consumer Behaviour and Halal Food Consumption,' Journal of Indonesian Social Sciences and Humanities, vol. 3 (2011): 151-160.

Soraji, A. J., Awang, M. D., \& Yusoff, A. N. M., 'Malaysia Halal Trust: Between Reality and Challenges,' International E-Journal of Advances in Social Sciences, vol. 3, no. 7 (2017): 197-204.

The Halal Journal: An Overview,' http://www.journal.com/artman/publish/ article_9.shtml., accessed on 12 July 2018.

Waqiuddin R., 'Review Halal Labels Regularly,' http://m.bt.com.bn/frontpagenews-national/2014/06/06/having-halal-certificate-logo-attached-foodproduct, accessed on 12 October 2018.

\section{Statutes}

Trade Description Act of 2011.

Halal Product Certification Act 2014.

Administration of Muslim Act revised on 2009. 
Jurnal Syariah, Jil. 27, Bil. 1 (2019) 173-200

\section{Cases}

Public Prosecutor v Angliss Singapore Pte Ltd [2006] SGDC 70. 